A-rkivoc

Free to Authors and Readers
A Platinum Open Access Journal

for Organic Chemistry
Paper

Arkivoc 2022, part iv, $80-98$

\title{
Synthesis and evaluation of benzochalcogenazole-benzimidazole derivatives as potential DNA-binding radioprotectors
}

\author{
Thomas Fellowes, ${ }^{a}$ Colin E. Skene, ${ }^{a}$ Roger F. Martin, ${ }^{a}$ Pavel Lobachevsky, ${ }^{b, c}$ Tze Cin Owyong, ${ }^{a, d}$ Yuning Hong, ${ }^{d}$ \\ and Jonathan M. White*a \\ School of Chemistry and Bio-21 Institute, University of Melbourne, Australia \\ ${ }^{b}$ Molecular Radiation Biology Laboratory, Cancer Research Division, Peter MacCallum Cancer Centre, \\ Melbourne, Australia \\ 'Advanced Analytical Technologies, Melbourne, Australia \\ ${ }^{d}$ Department of Chemistry and Physics, La Trobe Institute for Molecular Science, La Trobe University, Australia
} Email: whitejm@unimelb.edu.au

Received 11-03-2021

Accepted Manuscript 01-17-2022

Published on line $01-27-2022$

\section{Abstract}

Benzothiazole 6 and benzoselenazole 7, which are closely related to the bisbenzimidazole radioprotector bisbenzimidazole M2PB 20, were prepared by reaction of a common amide intermediate 13o with Lawesson's and Woolin's reagents, respectively. A simpler tellurazole derivative 19 was prepared using a different synthetic strategy. The DNA binding affinity of the three chalcogenazoles 6, 7, 19 and the parent benzimidazole 20 were assessed by means of spectrophotometric DNA titration experiments using 16-mer oligonucleotides with and without a single binding site. While M2PB 20 shows clear binding to the oligonucleotide containing an AATT binding site, no strong conclusions can be made regarding the interactions of 6, 7 or 19 with DNA, either in the presence, or absence of an AATT binding site. Fluorescence microscopy studies with HeLa cells clearly shows nuclear localisation of M2PB (20); fluorescence is almost exclusively in nuclei. By contrast, for the benzoselenazole 7, fluorescence is excluded from the nuclei. These results suggest that the proposed chalcogen bonding interactions involving $\mathbf{S}$, Se and Te in 6, 7, and $\mathbf{2 0}$ are not strong enough to impart the DNA binding behavior which is displayed by corresponding bis-benzimidazoles such as 20.

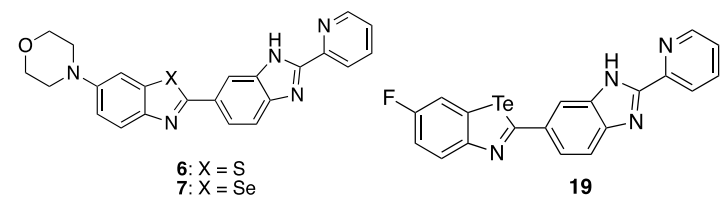

Keywords: Radioprotectors, chalcogen bonding, DNA groove binders, fluorescence microscopy DOI: https://doi.org/10.24820/ark.5550190.p011.684 


\section{Introduction}

Some DNA minor groove binding bisbenzimidazoles are known to protect biological materials from the effects of ionising radiation. Such radioprotection was first demonstrated for Hoechst 332581 and Hoechst $33342 \mathbf{2}$ in early studies on isolated plasmid DNA ${ }^{1,2}$ and on the clonogenic survival of cultured cells, and in vivo, with the compounds present during and after irradiation. ${ }^{3,4,5}$ These molecules bind in the minor groove of DNA in regions of three or more consecutive AT base pairs, ${ }^{6,7,8}$ a mode of binding that is largely facilitated by hydrogen bonding of the benzimidazole $\mathrm{N}-\mathrm{H}$ protons to hydrogen-bond acceptors at the floor of the minor groove in these regions. ${ }^{9,10}$ Subsequently we designed more potent bisbenzimidazole based radioprotectors, such as proamine 3 and methylproamine 4 . The report of improved radioprotection also included a crystal structure of the DNA/methylproamine complex..$^{11}$ There is evidence that the mechanism of radioprotection by this class of DNAminor groove binding molecules involves the repair of transient oxidative lesions in the DNA, that are precursors of more permanent lesions. ${ }^{12}$ The mechanism of this repair is believed to involve proton-coupled electron transfer from the DNA-binding ligand to the DNA, and then charge transfer along DNA between the bound ligand and the transient lesion. ${ }^{13}$ The candidate transient lesions include guanidine radical cations $\mathrm{G}^{+}$which results in formation of stable products such as 8 -oxoguanine. ${ }^{14}$ This mode of protection is quite distinct from the indirect mode of radioprotection that is provided by the radioprotector amifostine $\mathbf{5}$, a prodrug of the corresponding aminothiol, which like many other aminothiols, act principally by hydroxyl radical scavenging. ${ }^{15}$
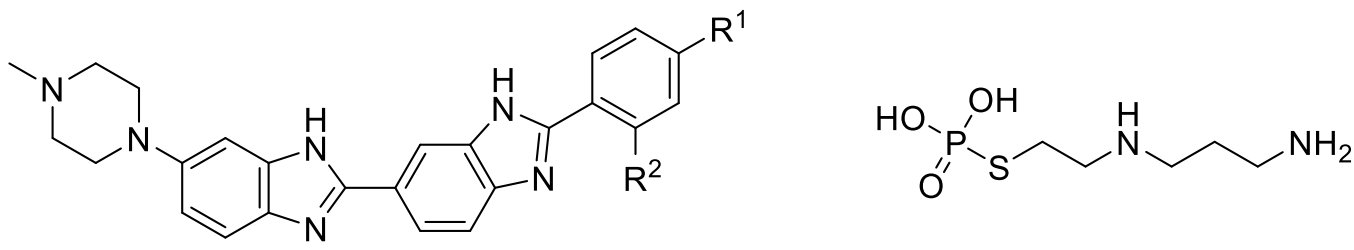

$$
\begin{aligned}
& \text { 1: } R^{1}=\mathrm{OH}, \mathrm{R}^{2}=\mathrm{H} \\
& \text { 2: } \mathrm{R}^{1}=\mathrm{CH}_{2} \mathrm{CH}_{3}, \mathrm{R}^{2}=\mathrm{H} \\
& \text { 3: } \mathrm{R}^{1}=\mathrm{NMe}_{2}, \mathrm{R}^{2}=\mathrm{H} \\
& \text { 4: } \mathrm{R}^{1}=\mathrm{NMe}_{2}, \mathrm{R}^{2}=\mathrm{Me}
\end{aligned}
$$

As part of a program aimed at discovering more potent radioprotectors we considered the incorporation of the chalcogens $\mathrm{S}$, Se and Te to replace one or both of the N-H groups in the bisbenzimidazole backbone of 1-4 and related molecules. Heavier group VI elements in particular sulfur have been observed to behave similarly to a $\mathrm{NH}$ group in biological systems..$^{16,17,18,19} \mathrm{~A}$ range of drugs have been developed that display this bioisosteric behavior. The origin of this behavior lies in the ability of certain $\mathrm{S}$, Se and Te containing molecules to participate in a non-covalent attractive interaction known as Chalcogen bonding, which arises when a molecule contains a polarized $\sigma$-bond between $\mathrm{S}$ (or $\mathrm{Se}, \mathrm{Te}$ ) and an electronegative substituent. ${ }^{20}$ Along the extension of this bond lies a region of positive electrostatic potential on the surface of the chalcogen atom, referred to as a $\sigma$-hole. This can interact with Lewis basic molecules in a manner which is similar in directionality, and often in strength, to $\mathrm{N}-\mathrm{H}$ hydrogen bonding (Figure 1). 


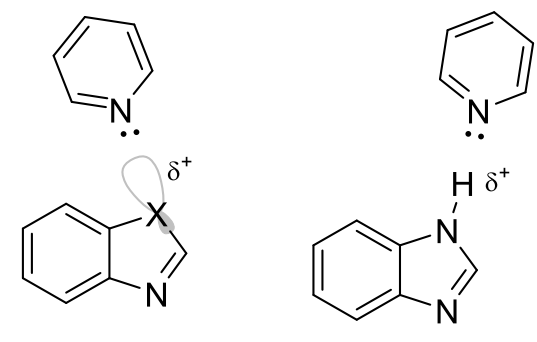

$\mathrm{X}=\mathrm{S}, \mathrm{Se}, \mathrm{Te}$

Figure 1. Schematic of chalcogen bonding in chalcogen substituted analogues to benzimidazole.

We aimed to exploit the chalcogen bonding properties of $S$, Se or Te to aid in binding of analogues of the bisbenzimidazoles 1-4 to DNA by replacement of the left-hand benzimidazole with a benzothiazole, benzoselenazole or benzotellurazole system (Figure 2), and to exploit the antioxidant properties of S, Se and Te containing functional groups in the design of potentially more potent radioprotectors.
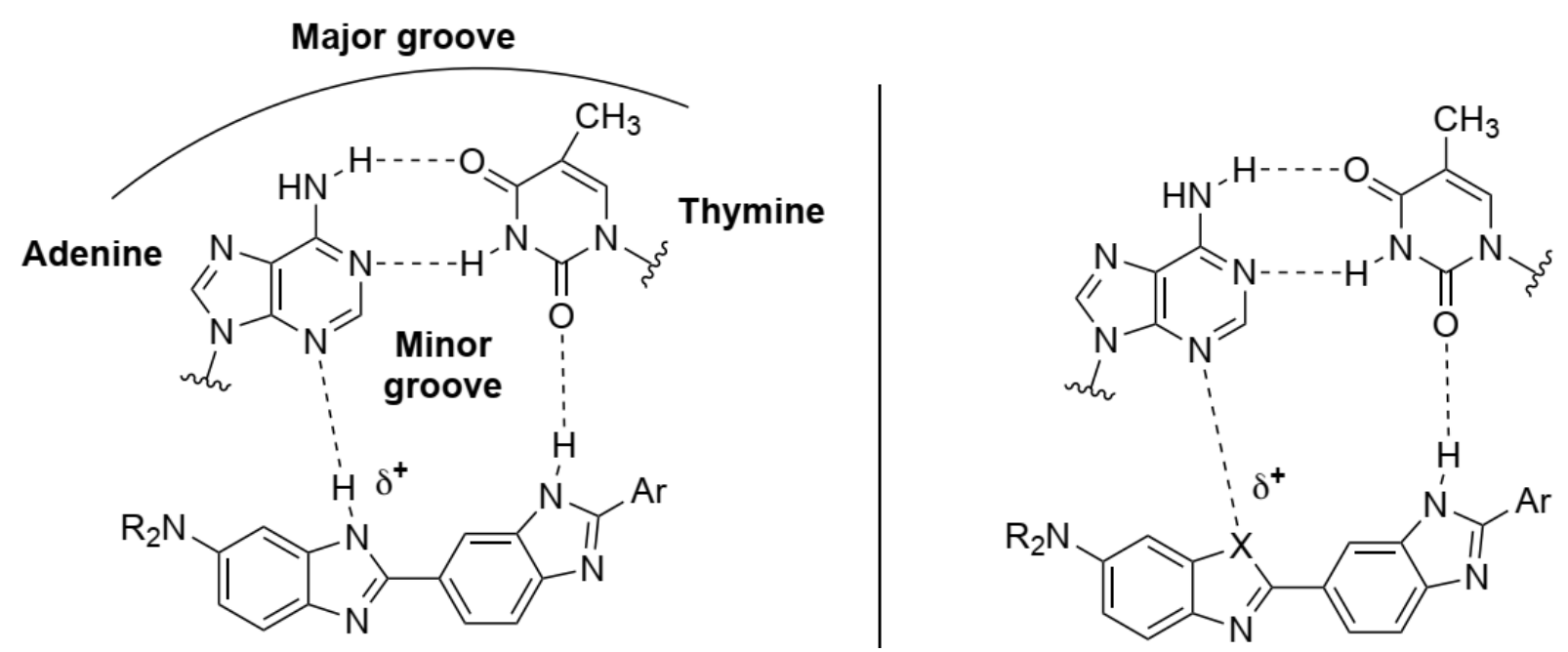

Figure 2. Proposed mode of binding of benzochalcogenazole-benzimidazole derivatives to the minor groove of DNA $(X=S$, Se or Te).

\section{Results and Discussion}

To test this proposal, we decided to prepare the morpholino-substituted benzothiazole and benzoselenazole analogues 6 and 7 which are based on the most active bisbenzimidazole radioprotectors that we have thus far prepared. ${ }^{21}$ The benzothiazole 6 was initially proposed to be synthesized by Jacobson's cyclisation, ${ }^{22}$ an oxidative cyclisation via a thioamide precursor. 


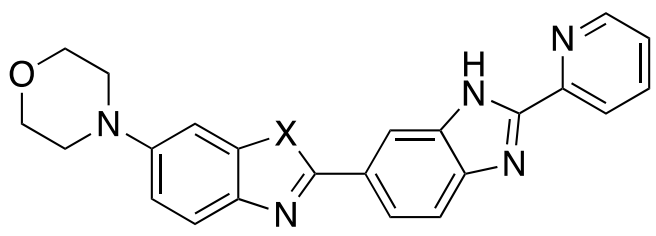

$$
\begin{aligned}
& \text { 6: } X=S \\
& \text { 7: } X=S e
\end{aligned}
$$

Thus, we embarked on the preparation of 6 as shown below in Scheme 1. Morpholino-substituted nitrobenzene $\mathbf{8}$ was reduced to the aniline $\mathbf{9}$ and then coupled to the acid chloride $\mathbf{1 0}$ to form an intermediate amide $11_{0}$ which was then converted to the thioamide $11_{s}$ by treatment with Lawesson's reagent in refluxing chlorobenzene. The Jacobson's cyclisation procedure uses stoichiometric potassium ferricyanide to oxidize the arene to a radical cation, which is captured by the sulfur atom to ultimately form the benzothiazole. When applied to this substrate, this procedure resulted in no reaction, even with heating. Other oxidants trialed include DDQ and sodium persulfate, neither of which gave the desired product.

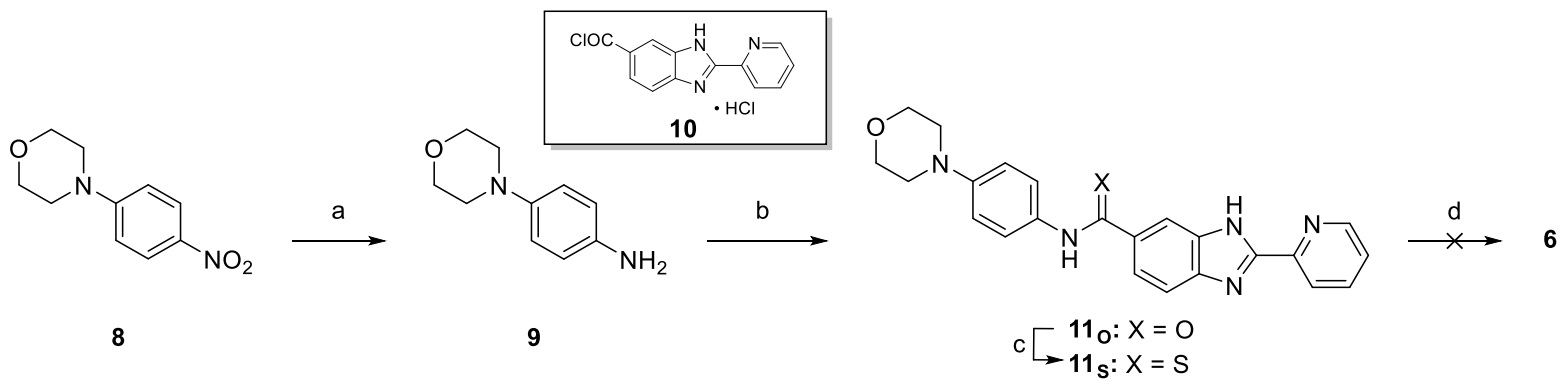

a) $\mathrm{H}_{2}, \mathrm{Pd} / \mathrm{C}$, ethanol; b) 10, DMAc, rt, $12 \mathrm{~h}$; c) Lawesson's reagent, $\mathrm{PhCl}$, reflux, $10 \mathrm{~h}$; d) oxidation with $\mathrm{K}_{3} \mathrm{Fe}(\mathrm{CN})_{6}, \mathrm{DDQ}$, or $\mathrm{Na}_{2} \mathrm{~S}_{2} \mathrm{O}_{8}$

Scheme 1. Attempted synthesis of benzothiazole via a Jacobson's oxidative cyclisation route.

A different strategy was then employed to construct the thiazole which involved the preparation of the fluorinated thioamide precursor $\mathbf{1 3}$, by a similar pathway to that described in Scheme 1 for the synthesis of $\mathbf{1 1}_{\mathbf{s}}$. It was conceived that a ring closure by intramolecular displacement of the fluorine leaving group might provide a viable synthesis of the benzothiazole 6 .

Using this approach, the precursor amide 13o was prepared in a similar fashion to that described in Scheme 1 but starting from fluoronitrobenzene 12. Upon treatment of 13o with Lawesson's reagent the benzothiazole 6 was formed directly, presumably via the intermediate thioamide $13 \mathrm{~s}$ which appears to undergo an intramolecular nucleophilic aromatic substitution under the relatively forcing reaction conditions. 


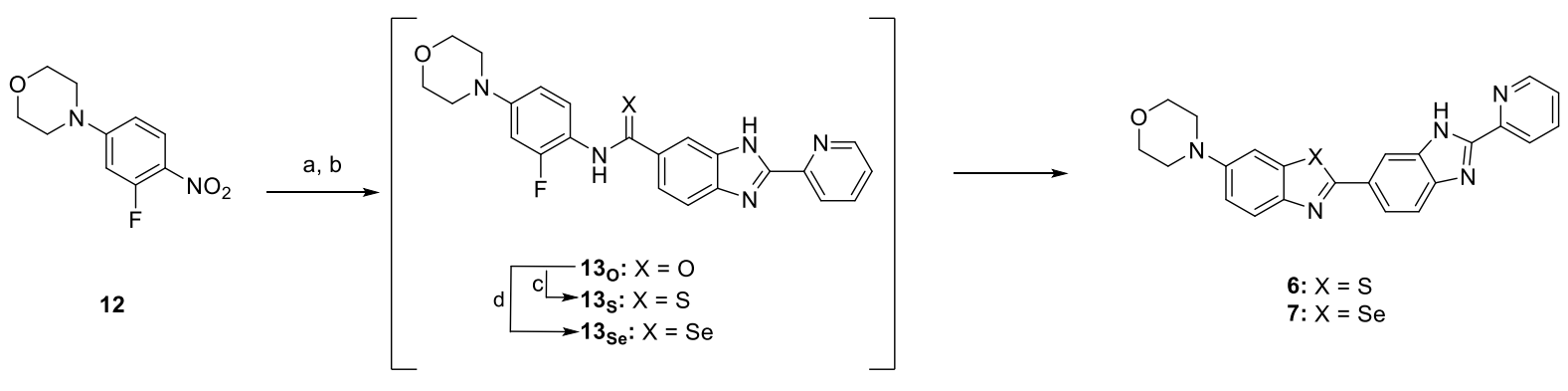

a) $\mathrm{H}_{2}, \mathrm{Pd} / \mathrm{C}$, ethanol; b) 10, DMAc, rt, $12 \mathrm{~h}$ c) Lawesson's reagent, $\mathrm{PhCl}$, reflux, $10 \mathrm{~h}$; d) Woollins' reagent, pyridine, $\mathrm{PhCl}$, reflux, $10 \mathrm{~h}$

Scheme 2. Alternate route to targets 6 and 7 .

Crystals of $\mathbf{6}$ suitable for X-ray structure analysis were obtained by evaporation from methanol. A thermal ellipsoid plot of $\mathbf{6} \cdot \mathbf{M e O H}$ is presented in Figure $3 .^{23}$

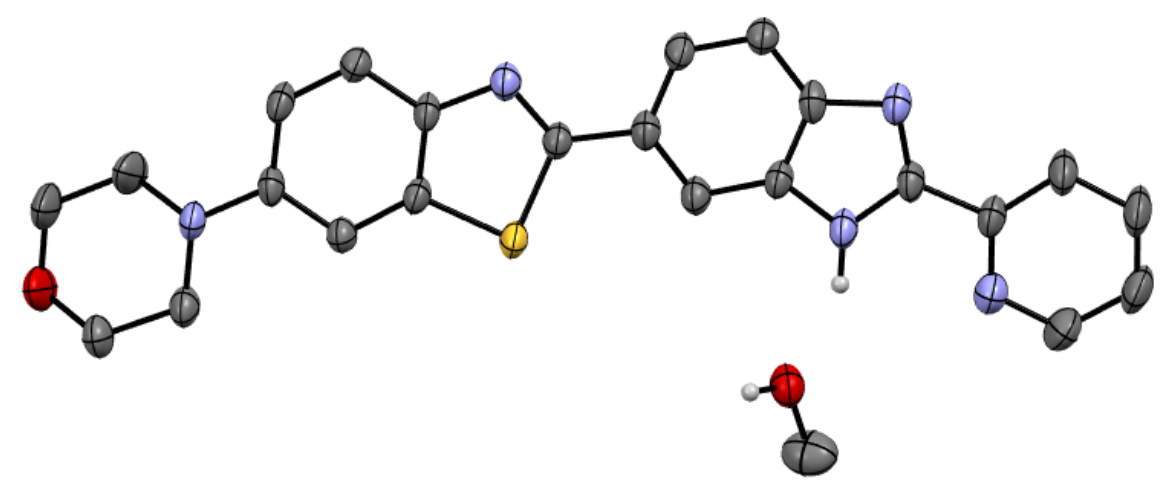

Figure 3. Thermal ellipsoid plot of $6 \cdot \mathrm{MeOH}$ ellipsoids are at the $50 \%$ probability level.

The benzoselenazole 7 was synthesized in a low yield in a similar fashion from the amide 130, using Woollins' reagent in a mixture of pyridine and chlorobenzene. Similarly, the intermediate selenoamide $13_{\mathrm{se}}$ was presumed to have formed initially, which then cyclised under the reaction conditions (Scheme 2). Weakly diffracting crystals were grown from DMSO and the atom connectivity was established on a poor-quality crystal (Figure 4).

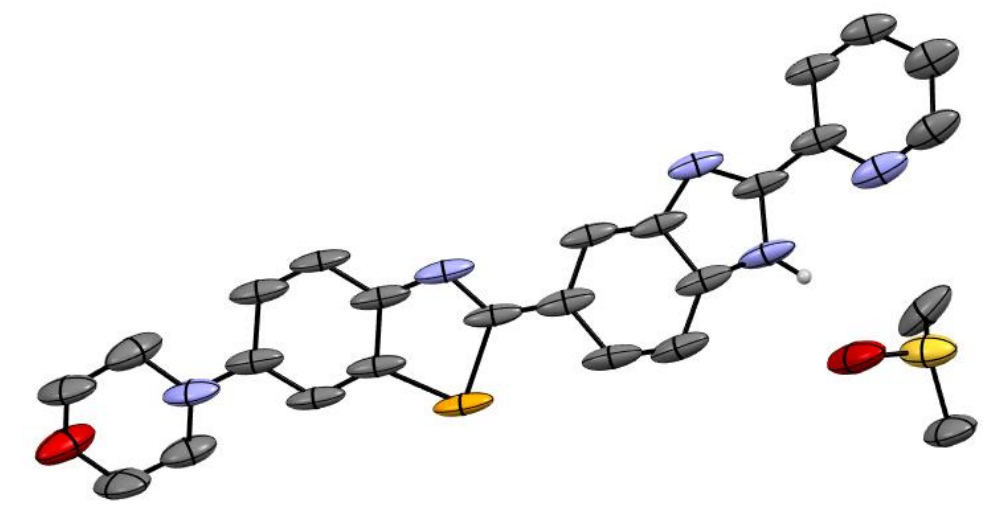

Figure 4. Thermal ellipsoid plot of 7-DMSO ellipsoids are at the 50\% probability level. 
Although heterocyclic systems containing tellurium are practically unheard of in drug development we were interested to prepare and compare the properties of a corresponding benzotellurazole analogue to the thiazole and selenazole 6 and 7, particularly given that tellurium is expected to form stronger chalcogen bonding interactions with Lewis bases. There is no analogous reagent to Lawesson's or Woollins' reagents for the incorporation of tellurium into an organic molecule, so an alternative approach was used to assemble the tellurium derivative 19 as outlined in Scheme 3.

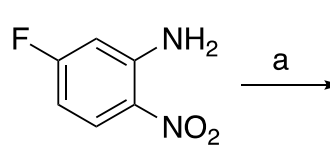

14

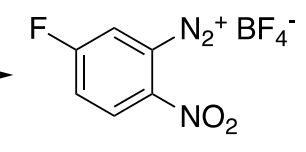

15

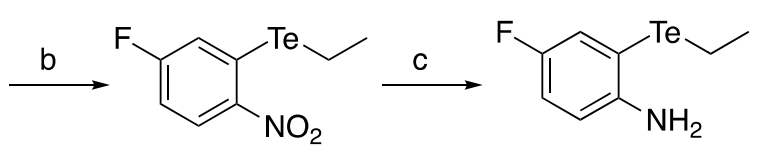

16
17

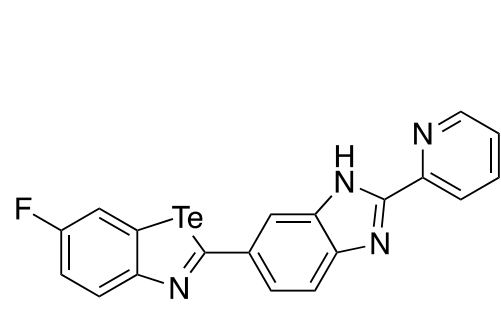

19

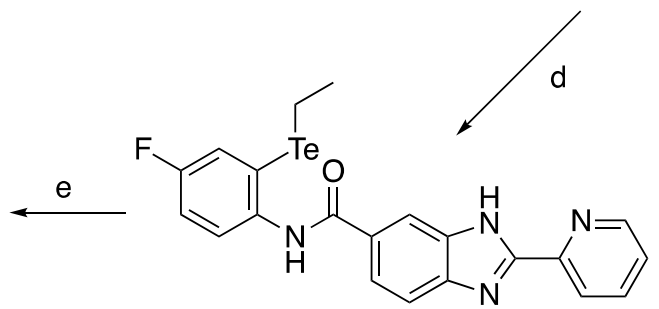

18

a) $\mathrm{BF}_{3}-\mathrm{OEt}_{2}$, tBuONO, $\mathrm{CH}_{2} \mathrm{Cl}_{2}$; b) (EtTe) $)_{2}$, KOAc, 18-crown-6; c) $\mathrm{NaBH}_{4} \mathrm{CoSO}_{4}$; d) 10, $\mathrm{DMAc} \mathrm{NEt}_{3}$; e) $\mathrm{POCl}_{3} \mathrm{NEt}_{3}$

Scheme 3: Synthesis of benzotellurazole 19.

Unfortunately, the exact Te analogue to the S, and Se heterocycles 6 and 7 could not be prepared as incorporation of morpholine into the aromatic ring, either from fluoronitrobenzene 14 or the tellurium derivative 16 resulted in failure of the reduction step (step c, Scheme 3). We have previously demonstrated that analogous 5" fluorinated bisbenzimidazole binds strongly to DNA, ${ }^{24}$ and therefore settled on 19 to investigate the interactions with DNA.

Diazotisation of aniline 14 was followed by treatment with diethyl ditelluride to provide the nitrobenzene derivative 16 which was characterised by single crystal X-ray diffraction (Figure 5). ${ }^{25}$ Reduction of 16 to provide the aniline 17 was followed by reaction of the acid chloride 10 to afford the amide 18 . Cyclisation of 18 provided a low yield of the benzotellurazole 19 after purification.

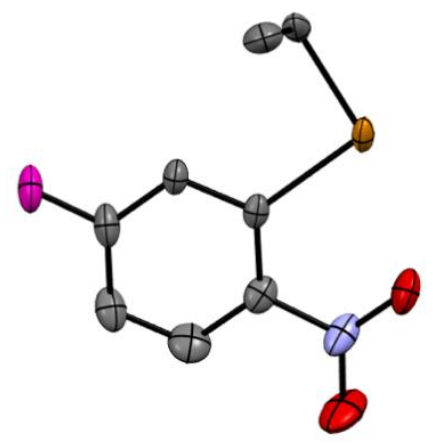

Figure 5. Thermal ellipsoid plot of one of the two independent molecules of 2-ethyltellanyl-substituted 4fluoronitrobenzene 16 . Ellipsoids are at the $50 \%$ probability level. 


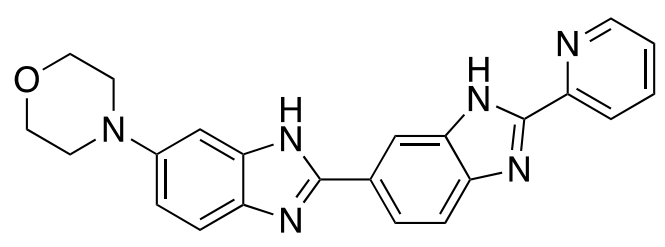

DNA binding assay for 6, 7, 19 and 20. Binding of analogues 6, 7, 19 and the corresponding bisbenzimidazole derivative $(\mathrm{M} 2 \mathrm{~PB}, \mathbf{2 0})^{21}$ to DNA was investigated using spectrophotometric titration with self-complementary 16-mer synthetic oligodeoxynucleotides (GeneWorks, Thebarton, SA, Australia). Two oligodeoxynucleotides were used, one comprising the sequence 5'-CGCGCGAATTCGCGCG-3' (DLB 16A) that incorporates a high affinity binding site for DNA minor-groove binding bisbenzimidazoles (AATT), and another comprising the sequence $5^{\prime}$ (CG) ${ }_{8}-3^{\prime}$ (DLB 16B) that served as a negative control for high affinity binding of bisbenzimidazoles. Solutions of investigated compounds at a concentration of $3-8 \mu \mathrm{M}$ in $1 \mathrm{~mL}$ of $20 \mathrm{mM}$ Tris pH 7.2, $100 \mathrm{mM} \mathrm{NaCl}$ and $10 \%$ DMSO (TEN+DMSO) in a spectrophotometric cuvette were titrated with DLB 16A or DLB 16B up to a maximum DNA base pairs concentration of $600-800 \mu \mathrm{M}$. The inclusion of DMSO was required to support solubility and to prevent adsorption to surfaces. The absorbance spectrum in the range from $300-400 \mathrm{~nm}$ was recorded following addition of each consecutive aliquot of DNA. Spectrophotometric measurements were performed on a Cary 300 UV-Vis spectrophotometer (Varian Australia Pty Ltd, Mulgrave, VIC, Australia). To compensate for the absorbance of DNA, the dual beam mode was employed. Referenced cuvette was filled with TEN+DMSO solution and titrated in parallel with same volumes of DNA solution. To calculate binding parameters $K_{d}$ (binding dissociation constant) and $N$ (frequency of binding sites), the set of absorbance spectra of DNA ligand solutions was analysed as described in detail in the Supplementary Information.

Summary of the results. Supplementary Figure S1 illustrates the analysis of absorbance spectra and calculation of binding parameters for the parent bisbenzimidazole M2PB 20. Titration of the ligand with DLB 16A oligonucleotide results in the shift of the absorbance peak towards longer wavelength characteristic to the DNA minor groove binding. ${ }^{9} \mathrm{~A}$ single isosbestic point for the set of spectra indicates single binding mode.

Absorbance spectra for titration with DLB 16A of compounds 6, 7, 19 and M2PB 20 for comparison are shown in Figure 5. For clarity, only spectra of the free ligand and its solution with the highest DNA concentration are shown. To assist in the interpretation of the results, absorbance spectra for titration with DLB 16B of the same compounds are shown in Figure 6.

Analysis of the data presented in these Figures leads to the following interpretation (summarised also in Table 1).

M2PB 20 shows clear DNA minor groove binding to a single binding site on DLB 16A molecule as evidenced by the difference in spectra of free ligand and DNA-ligand solution. Values of DNA binding parameters are: $K_{d}=$ $3.92 \pm 0.30 \mu \mathrm{M}, N=0.0451 \pm 0.0021 / \mathrm{bp}$. The lack of change in the spectra following titration with DLB 16B oligonucleotide indicates the absence of different (non-specific) modes of binding and supports site specificity for minor groove binding. The theoretical value for N for DLB 16A, with a single central binding site, is 0.0625 (1/16).

For compound 6, the changes in spectra following titration with DLB 16A indicate a trend for minor groove binding. The extent of changes, however, is small and not sufficient to obtain quantitative results. It might indicate very weak minor groove binding. Following titration with DLB 16B, compound 6 shows an unusual increase of absorbance without any shift of wavelength. The changes of spectra can potentially be interpreted 
as some sort of binding, however due to the conservation of spectrum shape (lack of shift, proportional absorbance change) quantitation is not possible. The lack of similar changes for titration with DLB 16A doesn't support the involvement of binding in the observed changes. The changes might be a result of some experimental artefact. It is interesting, however, that similar changes were observed for titration of compound 6 with DLB 16C oligonucleotide (data not shown) that contains a different binding site - ATAT.

For compound 7 , the spectrum of the free ligand shows two absorbance peaks, and the changes in spectra are similar for both titration experiments (DLB 16A and DLB 16B) that show a decrease in absorbance without detectable wavelength shift. This observation indicates the lack of (or very weak) high affinity binding. The changes, however, can be interpreted and quantitatively analysed as some sort of non-specific binding, given that the shape of the spectra changes as reflected by relatively different peak height for free ligand and DNAligand solution for two peaks observed in spectra. The quantitative analysis was done assuming a fixed value for $\mathrm{N}=1 \mathrm{bp}^{-1}$, since otherwise it results in unreasonably high $\mathrm{N}$ values. It is worthwhile to note that $\mathrm{N}=1$ is also a high value since it means one binding site for each base pair (16 binding sites per oligonucleotide molecule). Large $\mathrm{N}$-values indicate that a substantial amount of ligand is bound even at very low DNA concentrations. One of the interpretations for such observation is that ligand self-aggregates on the first DNA bound molecule.

For tellurium derivative 19, the changes in spectra feature general decrease of absorbance for both titration experiments (DLB 16A and DLB 16B), however there is some trend for the increase at higher wavelength in case of DLB 16A. The latter observation might be interpreted as a contribution of minor groove binding, however the dominating mode of binding is non-specific binding that is observed for both oligonucleotides. The quantitative analysis is possible for both cases and results in large $\mathrm{N}$ values. In this context the result is similar to compound 6, prompting for similar interpretation of this binding component. For DLB 16A however, the analysis results in somewhat more accurate values of parameters and $\mathrm{N}<1$. This result supports the assumption that some minor groove binding is present for this compound. 
A

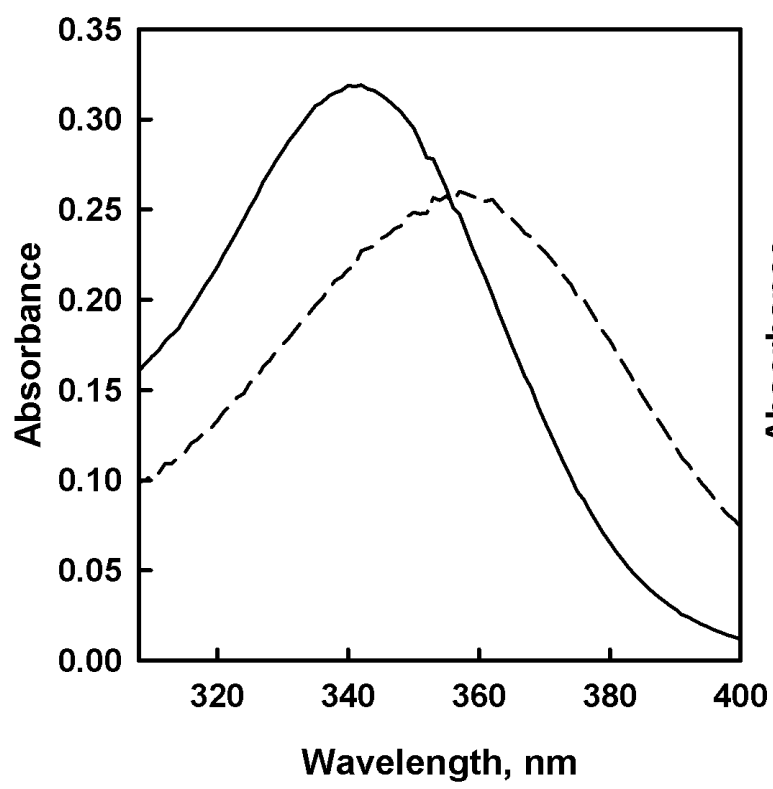

C

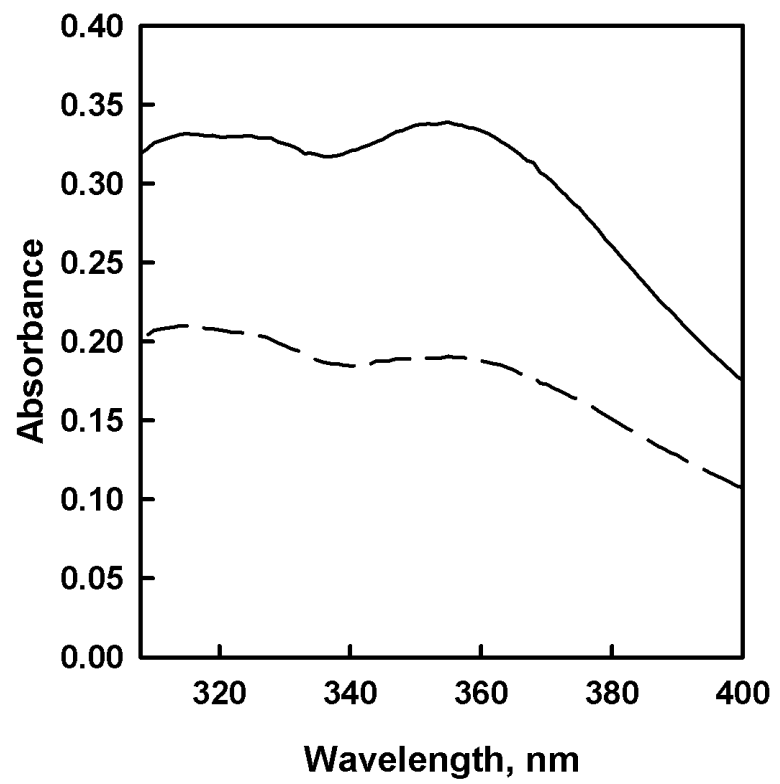

B

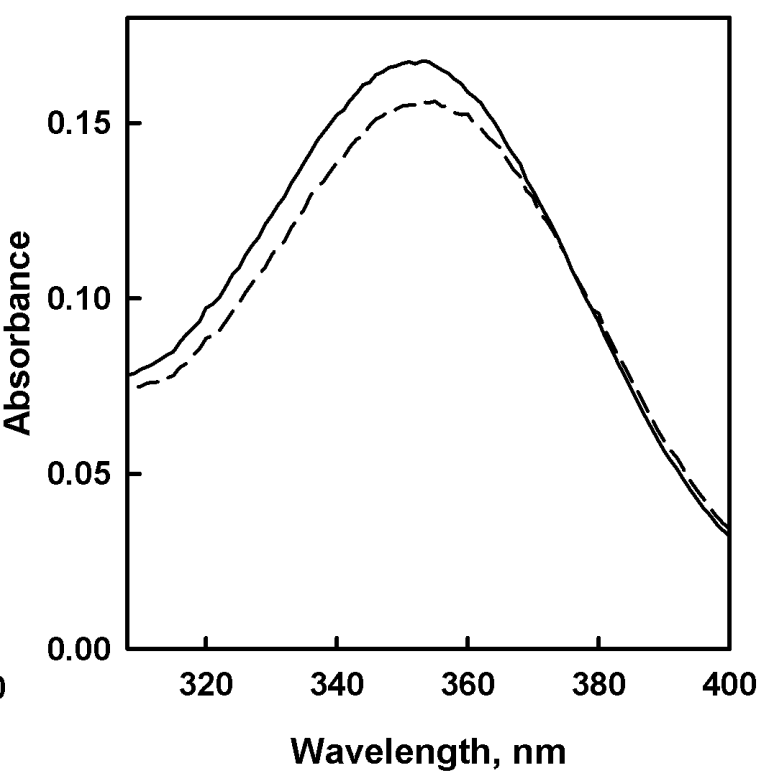

D

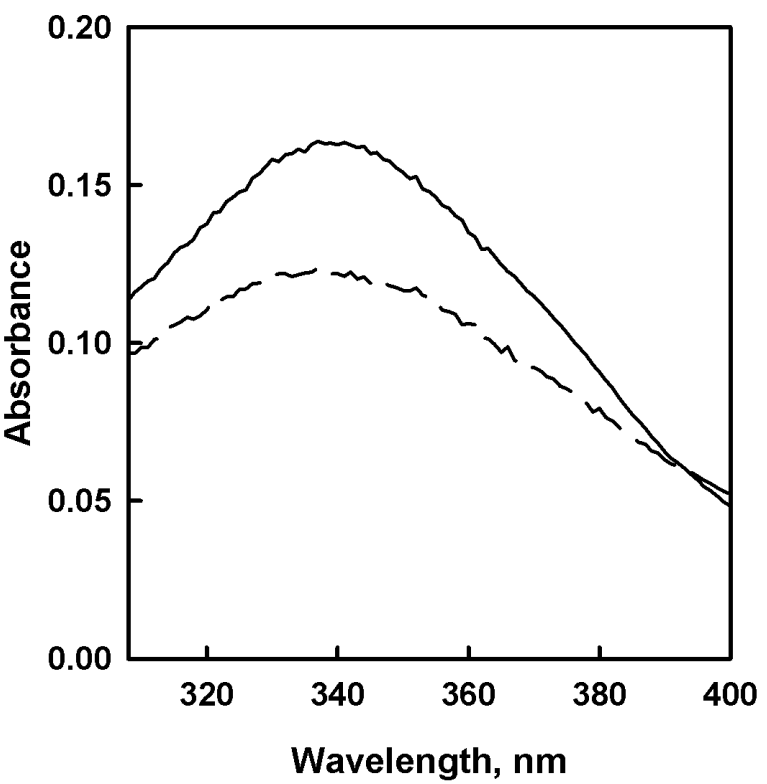

Figure 5. Absorbance spectra of M2PB 20 (A) and compound $\mathbf{6}$ (B) , 7 (C), and 19 (D) following titration with DLB $16 \mathrm{~A}$ oligonucleotide. Solid lines represent spectrum of free ligand and dashed lines - spectrum of ligand-DNA solution at the last titration point (highest DNA concentration). Full sets of spectra are shown in Supplementary Figure S2. 
A
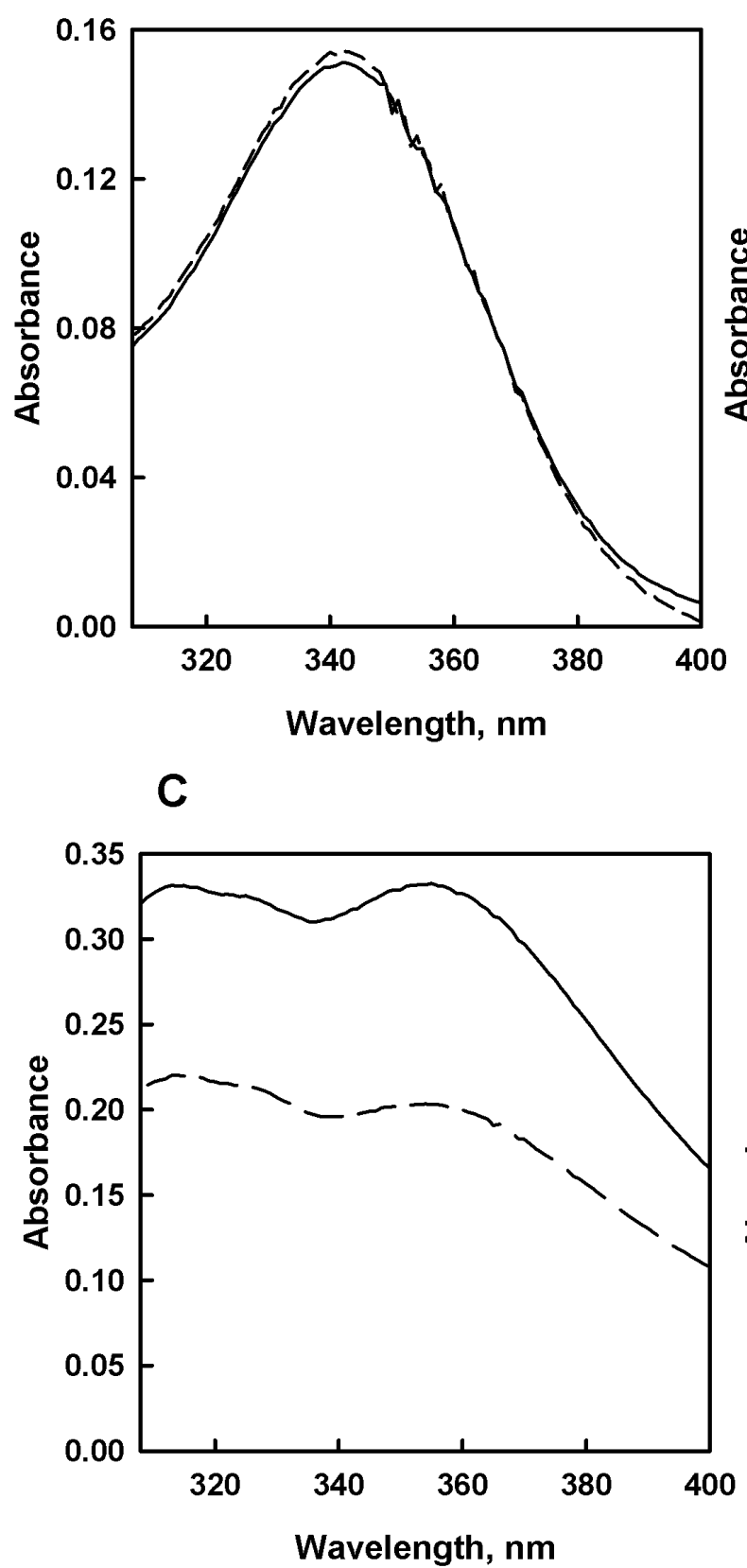

B

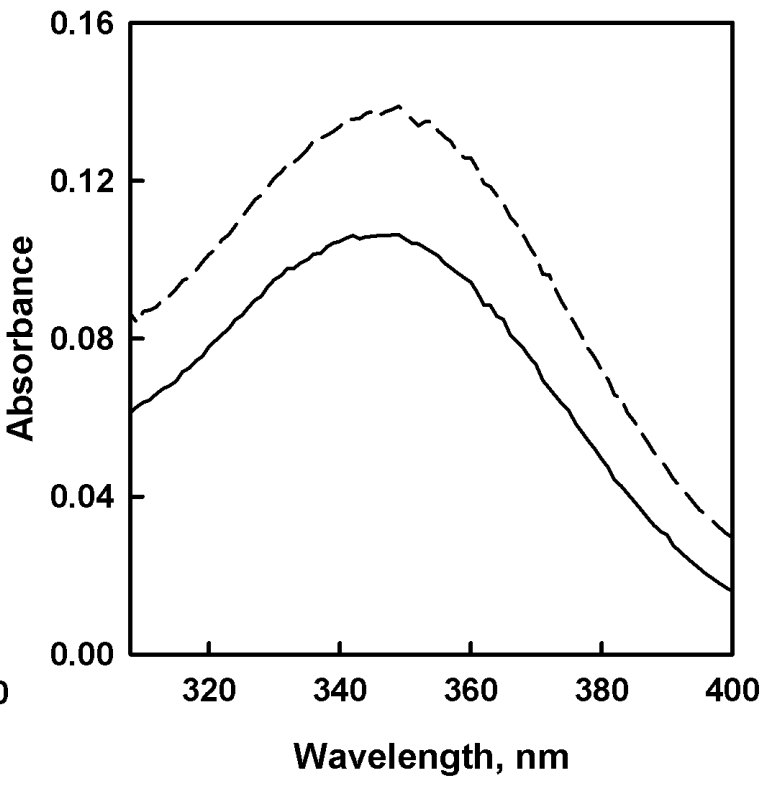

D

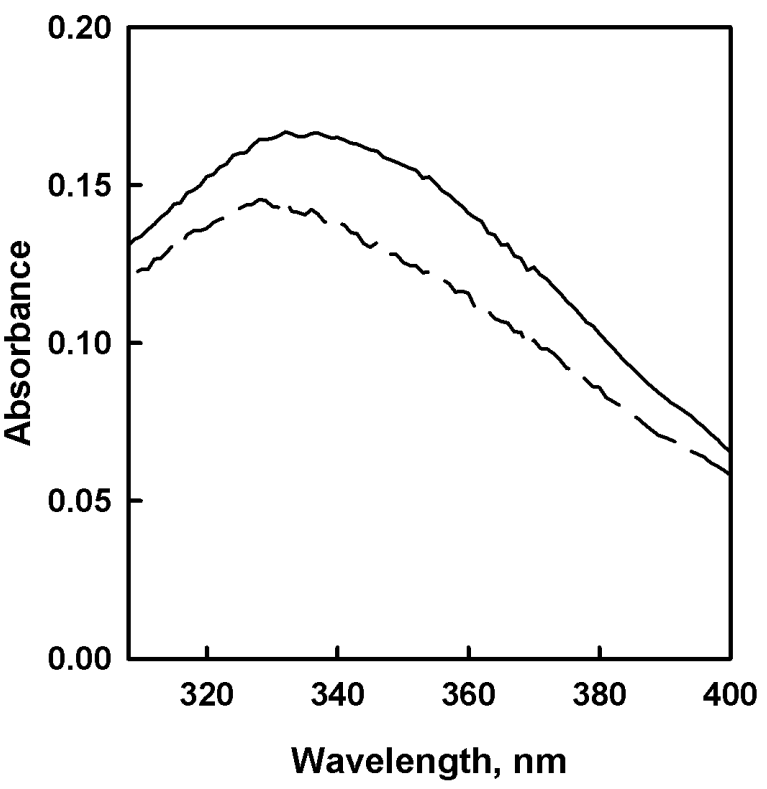

Figure 6. Absorbance spectra of M2PB (A) and compounds $6(B), 7(C)$, and 19 (D), following titration with DLB 16B oligonucleotide. Solid lines represent spectrum of free ligand and dashed lines - spectrum of ligand-DNA solution at the last titration point (highest DNA concentration). Full sets of spectra are shown in Supplementary Figure S3. 
Table 1. Summary of DNA binding for compounds 6, 7, 19 and 20

\begin{tabular}{|c|c|c|c|c|}
\hline \multirow{2}{*}{ Compound } & \multicolumn{2}{|c|}{ DLB 16A } & \multicolumn{2}{|c|}{ DLB 16B } \\
\hline & Spectrum change & Parameters & Spectrum change & Parameters \\
\hline M2PB 20 & $\begin{array}{l}\text { Peak shift 341- } \\
\quad 350 \mathrm{~nm}\end{array}$ & $\begin{array}{c}\mathrm{K}_{\mathrm{d}}=3.92 \pm 0.30 \mu \mathrm{M} \\
\mathrm{N}=0.0451 \pm 0.002 \\
1 / \mathrm{bp}\end{array}$ & No change & $\mathrm{N} / \mathrm{A}$ \\
\hline 6 & $\begin{array}{l}\text { Peak shift 352- } \\
354 \mathrm{~nm}\end{array}$ & Ambiguous & $\begin{array}{l}\text { Abs increased, no } \\
\text { peak shift }\end{array}$ & N/A \\
\hline 7 & $\begin{array}{l}\text { Abs decreased, } \\
\text { shape changed }\end{array}$ & $\begin{array}{c}\text { Ambiguous, } \\
\mathrm{K}_{\mathrm{d}}=3.8 \pm 6.2 \mu \mathrm{M} \\
\text { at } \mathrm{N}=1.01 / \mathrm{bp} \\
\text { (fixed) }\end{array}$ & $\begin{array}{l}\text { Abs decreased, } \\
\text { shape changed }\end{array}$ & $\begin{array}{c}\text { Ambiguous, } \\
\mathrm{K}_{\mathrm{d}}=2.0 \pm 1.2 \mu \mathrm{M} \\
\text { at } \mathrm{N}=1.01 / \mathrm{bp} \text { (fixed) }\end{array}$ \\
\hline 19 & $\begin{array}{c}\text { Peak Abs } \\
\text { decrease, at high } \\
\text { WL some } \\
\text { increase }\end{array}$ & $\begin{array}{c}\mathrm{K}_{\mathrm{d}}=7.9 \pm 8.4 \mu \mathrm{M} \\
\mathrm{N}=0.77 \pm 0.681 / \mathrm{bp}\end{array}$ & Abs decrease & $\begin{array}{c}\text { Ambiguous, } \\
\mathrm{K}_{\mathrm{d}}=73 \pm 500 \mu \mathrm{M} \\
\text { at } \mathrm{N}=1.01 / \mathrm{bp} \text { (fixed) }\end{array}$ \\
\hline
\end{tabular}

Given the stark difference between the apparent DNA binding affinity of the selenium analogue $\mathbf{7}$ and the parent bis-benzimidazole $\mathbf{2 0}$ we were interested to compare the cell localisation of these two dyes by looking at their distributions in HeLa cells as examined by confocal laser scanning microscopy (CLSM) (Figure 7). Both M2PB 20 and 7 can be excited by $405 \mathrm{~nm}$ laser. The CLSM images clearly show that M2PB 20 localises in the nuclei of the cells. This is consistent with our other experimental results where $\mathbf{2 0}$ has a high affinity for the minor groove of DNA. Such binding mode drives the diffusion and accumulation of 20 into the nucleus. The known enhancement of fluorescence of bisbenzimidazoles such as $\mathbf{2 0}$ when bound to DNA, by approximately 30 -fold ${ }^{26}$ does however bias the apparent preference for the nucleus. For example, in the case of similar nuclear localisation for methylproamine, analysis of the ligand in isolated nuclei indicates that only few \% of the total cellular ligand is in the nucleus. ${ }^{27}$ In contrast the selenium analogue7 appears to be completely excluded from the nucleus, consistent with the lack of apparent binding discussed above. Exclusion from the nucleus suggests that $\mathbf{7}$ perhaps has a higher affinity for binding sites in the cytoplasm. 
Dye Only

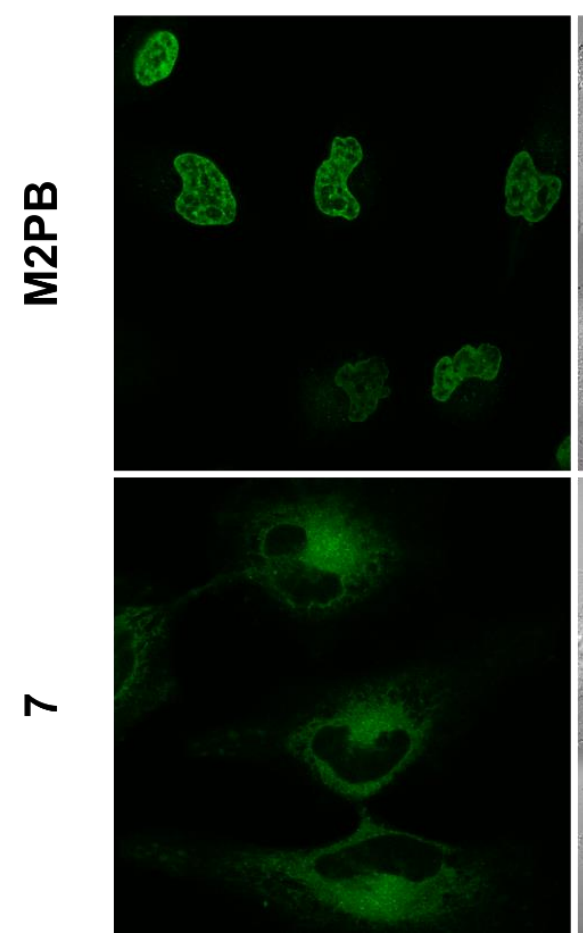

Brightfield

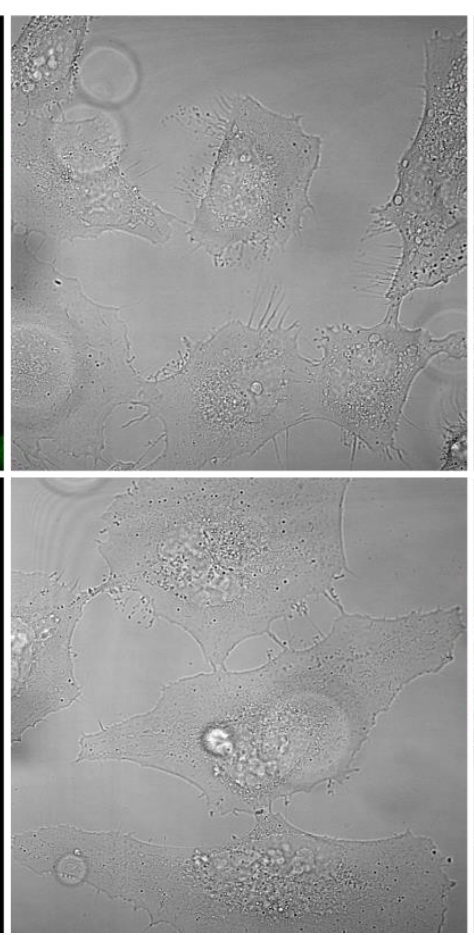

Merge

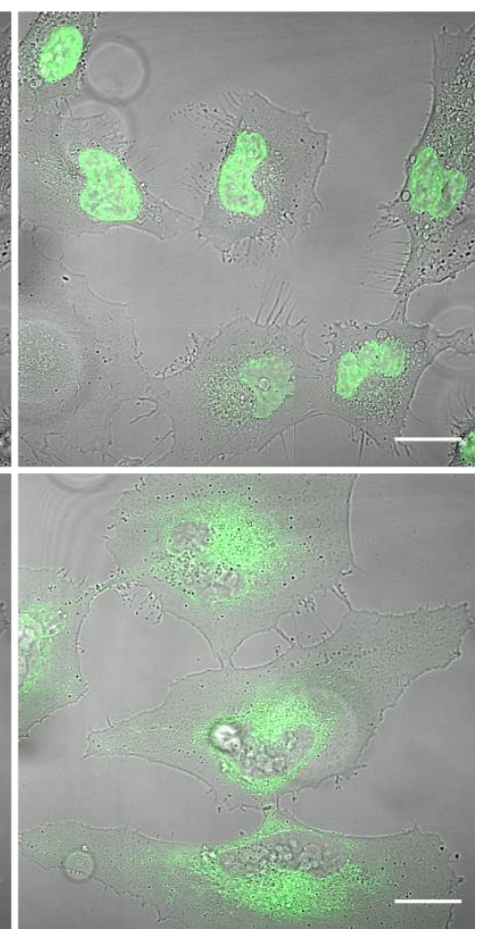

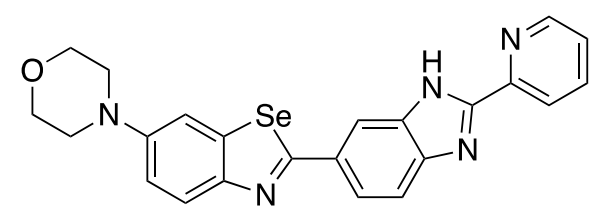

7

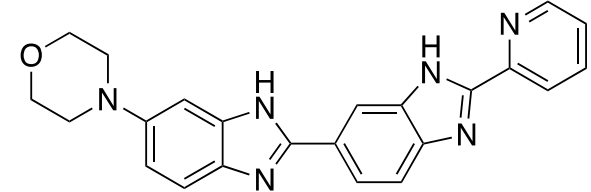

20

Figure 7. Cell localization experiments. Confocal images of intracellular distribution of M2PB (20) and 7 stained HeLa cells. HeLa cells were stained with the respective dyes (green) at $5 \mu \mathrm{M}$ concentration for $0.5 \mathrm{~h}$ before fixation. Scale bar, $20 \mu \mathrm{m}$.

\section{Conclusions}

Benzothiazole 6 and benzoselenazole 7 which are closely related to the radioprotector bisbenzimidazole M2PB 20, were prepared by reaction of a common amide intermediate 130 with Lawesson's and Woolin's reagents respectively. The simpler tellurazole derivative 19 was prepared using a different synthetic strategy. The DNA binding affinity of the three chalcogenazoles 6, 7, 20 and the parent benzimidazole 20 were assessed using spectrophotometric DNA titration experiments using 16-mer oligonucleotides with and without a single binding site. While M2PB 20 shows clear binding to the nucleotide containing an AATT binding site no strong conclusions can be made regarding the interactions of 6, 7 or 19 with DNA, either in the presence, or absence of an AATT binding site. Cell localisation assays on HeLa cells with one of these derivatives (7) shows that this molecule does not enter the nucleus, in contrast to M2PB (20), a known DNA-minor groove binder which was assessed for comparison and shows significant nuclear uptake. These results suggest that the proposed chalcogen bonding 
interactions involving S, Se and Te in 6, 7, and $\mathbf{2 0}$ are not strong enough to impart the DNA minor-groove binding behaviour which is displayed by corresponding bisbenzimidazoles such as 20 .

\section{Experimental Section}

General. All chemicals were of analytical grade and used as received from commercial suppliers without further purification except where otherwise indicated. Anhydrous solvents were dispensed from Sigma-Aldrich SureSeal ${ }^{\mathrm{TM}}$ bottles by syringe. Air and moisture sensitive reactions were conducted in oven-dried glassware (140 ${ }^{\circ} \mathrm{C}$ ) under a nitrogen or argon atmosphere. Inert gases were dried by passage over activated $4 \AA$ molecular sieves.

Analytical thin layer chromatography (TLC) was performed on aluminium backed $2 \mathrm{~mm}$ thick Merck Kieselgel silica gel $60 \mathrm{~F}_{254}$ sheets. The chromatograms were visualised under UV light ( $\lambda=254$ or $\left.365 \mathrm{~nm}\right)$. Flash chromatography was carried out using a Biotage Isolera One with Reveleris silica gel cartridges, or manually using Merck silica gel 60 (230-400) mesh.

Nuclear magnetic resonance (NMR) spectra for ${ }^{1} \mathrm{H}$ and ${ }^{13} \mathrm{C}$ nuclei were recorded as solutions in the stated solvent at ambient temperature $\left(25^{\circ} \mathrm{C}\right)$ using an Agilent $400-\mathrm{MR}$ operating at 400 and $100 \mathrm{MHz}$, respectively, an Agilent DD2 system operating at 500 and $125 \mathrm{MHz}$, or a Bruker BIO600 operating at 600 and $150 \mathrm{MHz}$. ${ }^{1} \mathrm{H}$ NMR spectra were referenced to residual solvent peaks; residual $\mathrm{CD}_{2} \mathrm{HOD}(\delta 3.31)$ in methanol- $d_{4}$, residual chloroform $(\delta$ 7.26) in $\mathrm{CDCl}_{3}$, residual DMSO- $d_{5}(\delta 2.50)$ in DMSO- $d_{6}$. The addition of a few drops of d-trifluoroacetic acid (TFAd) to solutions of the benzimidazole compounds was found to reduce peak broadening and enhance the resolution of multiplets in the aromatic region, and are designated (solvent + TFA-d). The ${ }^{1} \mathrm{H}$ NMR chemical shifts $(\delta)$ are reported as parts per million ( $\mathrm{ppm})$, followed by multiplicity (s: singlet, br s: broad singlet, d: doublet, dd: doublet of doublets, ddd: doublet of doublet of doublets, t: triplet, td: triplet of doublets, m: multiplet), coupling constant(s) $(J)$ given in Hertz $(\mathrm{Hz})$, and integration. Proton-decoupled ${ }^{13} \mathrm{C} N \mathrm{NM}$ chemical shifts are referenced on the centre peak of the solvent used: methanol- $d_{4}(\delta 49.0), \mathrm{CDCl}_{3}(\delta 77.2), \mathrm{DMSO} d_{6}(\delta 39.5)$ and the signals are reported as chemical shift (ppm), followed by any observed multiplicity and coupling constants.

High-resolution mass measurements (HRMS:ESI) were performed using a Thermo NanoLC/Q Exactive Plus mass spectrometer. Melting points were determined using a Stanford Research Systems MPA120 EZMelt.

Nitrobenzene derivatives $\mathbf{8}, \mathbf{1 2}$, and $\mathbf{1 4}$ were prepared as previously described in the literature or obtained commercially. ${ }^{28}$ Diethyl ditelluride was prepared according to the method of Levanova et al. ${ }^{29}$

General procedure for the catalytic reduction of nitrobenzenes 8 and 12 . Palladium on carbon $(5 \% \mathrm{w} / \mathrm{w}, 0.30$ g) was added to a solution of the appropriate nitrobenzene $(7.4 \mathrm{mmol})$ in ethanol $(100 \mathrm{~mL})$ and stirred under hydrogen (1 atm) for $18 \mathrm{~h}$. The mixture was filtered through celite under an argon atmosphere, rinsing with ethanol. The filtrate was concentrated and dried in vacuo affording the crude aniline, which was used without purification.

4-Morpholinoaniline 9 (from 8). lavender crystals yield 98\%, mp 103.2-103.7 ${ }^{\circ} \mathrm{C} .{ }^{1} \mathrm{H} \mathrm{NMR}\left(400 \mathrm{MHz}^{\mathrm{CDCl}} 3\right) \delta$ 2.97-3.06 (m, 4H), 3.44 (br s, 2H), 3.81-3.89 (m, 4H), 6.67 (d, J $8.6 \mathrm{~Hz}, 2 \mathrm{H}), 6.80$ (d, J 9.0 Hz, 2H).

2-Fluoro-4-morpholinoaniline (from 12). purple crystals, yield 97\%. ${ }^{1} \mathrm{H} \mathrm{NMR}\left(400 \mathrm{MHz}^{\mathrm{CDCl}} \mathrm{CD}_{3} \delta 2.95-3.05(\mathrm{~m}\right.$, 4H), 3.78-3.88 (m, 4H), $6.55(\mathrm{~d}, J 8.6 \mathrm{~Hz}, 1 \mathrm{H}), 6.63(\mathrm{dd}, J 13.5,2.2 \mathrm{~Hz}, 1 \mathrm{H}), 6.72(\mathrm{t}, J 9.4 \mathrm{~Hz}, 1 \mathrm{H})$. 
Preparation of 2-(pyrid-2-yl)benzimidazole carbonyl chloride hydrochloride (10). 2-(Pyrid-2-yl)benzimidazole carboxylic acid ${ }^{30}$ was prepared from 3,4-diaminobenzoic acid and 2-pyridinecarboxaldehyde following a literature procedure. The carboxylic acid $(2.788 \mathrm{~g}, 8.815 \mathrm{mmol})$ was then converted to the acid chloride 10 by refluxing in thionyl chloride $(20 \mathrm{~mL})$ for $18 \mathrm{~h}$, followed by removal of the excess thionyl chloride in vacuo giving 10 as a light brown powder $(2.266 \mathrm{~g}, 66 \%)$ which was used without further purification. ${ }^{1} \mathrm{H} \mathrm{NMR}(500 \mathrm{MHz}$, DMSO-d $)) \delta 7.76(\mathrm{ddd}, J 7.8,4.8,1.2 \mathrm{~Hz}, 1 \mathrm{H}), 7.88(\mathrm{~d}, J 8.4 \mathrm{~Hz}, 1 \mathrm{H}), 8.08(\mathrm{dd}, J 8.4,1.8 \mathrm{~Hz}, 1 \mathrm{H}), 8.21(\mathrm{td}, J 7.8,1.8$ $\mathrm{Hz}, 1 \mathrm{H}), 8.33(\mathrm{~d}, J 0.6 \mathrm{~Hz}, 1 \mathrm{H}), 8.73(\mathrm{~d}, J 7.8 \mathrm{~Hz}, 1 \mathrm{H}), 8.90(\mathrm{~d}, J 4.2 \mathrm{~Hz}, 1 \mathrm{H})$.

General procedure for the preparation of amides $11^{\circ}$ and 130 . Acid chloride 10 (7.7 mmol, 1.05 equiv) was dissolved in anhydrous $\mathrm{N}, \mathrm{N}$-dimethylacetamide $(40 \mathrm{~mL})$ under nitrogen. To this was added a solution of the appropriate crude aniline $(7.3 \mathrm{mmol})$ in a further $20 \mathrm{~mL}$ of anhydrous $N, N$-dimethylacetamide. The mixture was stirred at room temperature under nitrogen for $18 \mathrm{~h}$, then diluted with water $(100 \mathrm{~mL})$, the $\mathrm{pH}$ adjusted to 8 using $0.8 \mathrm{M}$ aqueous $\mathrm{NaHCO}_{3}$, and the resulting precipitate filtered off and dried in vacuo, affording the amide. $\mathbf{N}$-(4-Morpholinophenyl)-2-(pyrid-2-yl)-1H-benzo[d] imidazole-6-carboxamide 11。 (from aniline 9); brown-grey solid, yield 85\%, mp $220{ }^{\circ} \mathrm{C}$ (dec). ${ }^{1} \mathrm{H}$ NMR (400 MHz, DMSO-d 6 + TFA-d) $\delta$ 2.96-3.16 (m, 4H), 3.63-3.82 (m, 4H), $6.94(\mathrm{~d}, J 9.0 \mathrm{~Hz}, 2 \mathrm{H}), 7.50-7.59(\mathrm{~m}, 1 \mathrm{H}), 7.60-7.78(\mathrm{~m}, 3 \mathrm{H}), 7.89(\mathrm{~d}, J 8.2 \mathrm{~Hz}, 1 \mathrm{H}), 8.02(\mathrm{t}, J 7.2 \mathrm{~Hz}, 1 \mathrm{H}), 8.29(\mathrm{br} \mathrm{s}$, $1 \mathrm{H}), 8.37(\mathrm{~d}, J 7.8 \mathrm{~Hz}, 1 \mathrm{H}), 8.76(\mathrm{~d}, J 3.9 \mathrm{~Hz}, 1 \mathrm{H}), 10.13(\mathrm{~s}, 1 \mathrm{H}) .{ }^{13} \mathrm{C}$ NMR $\left(100 \mathrm{MHz}, \mathrm{DMSO}-d_{6}+\mathrm{TFA}-d\right) \delta 49.5,66.5$, $115.8,122.0,122.3,123.1,125.7,130.2,132.3,138.2,147.6,148.2,150.0,152.9,165.8 . \mathrm{MS}$ (ESI +ve) $\mathrm{m} / \mathrm{z}$ $400.1807\left(\mathrm{MH}^{+}\right) \mathrm{C}_{23} \mathrm{H}_{22} \mathrm{~N}_{5} \mathrm{O}_{2}{ }^{+}$requires 400.1768 ( $\left.\Delta=9 \mathrm{ppm}\right)$. $\mathbf{N}$-(2-Fluoro-4-morpholinophenyl)-2-(pyrid-2-yl)1H-benzo[d]imidazole-6-carboxamide 13o (from 2-fluoro-4-morpholinoaniline); grey solid, yield $42 \% .{ }^{1} \mathrm{H} N M R$ $\left(400 \mathrm{MHz}, \mathrm{DMSO}-d_{6}+\mathrm{TFA}-d\right) \delta 3.13(\mathrm{br} \mathrm{s}, 4 \mathrm{H}), 3.73$ (br s, 4H), 6.77 (d, J $\left.8.6 \mathrm{~Hz}, 1 \mathrm{H}\right), 6.86(\mathrm{~d}, J 13.3 \mathrm{~Hz}, 1 \mathrm{H}), 7.35$ $(\mathrm{t}, J 8.8 \mathrm{~Hz}, 1 \mathrm{H}), 7.52-7.62(\mathrm{~m}, 1 \mathrm{H}), 7.71(\mathrm{~d}, J 8.2 \mathrm{~Hz}, 1 \mathrm{H}) 7.90(\mathrm{~d}, J 8.2 \mathrm{~Hz}, 1 \mathrm{H}), 8.04(\mathrm{t}, J 7.4 \mathrm{~Hz}, 1 \mathrm{H}), 8.29(\mathrm{br} \mathrm{s}$, $1 \mathrm{H}), 8.37(\mathrm{~d}, J 7.4 \mathrm{~Hz}, 1 \mathrm{H}), 8.77(\mathrm{~d}, J 3.5 \mathrm{~Hz}, 1 \mathrm{H}), 9.91(\mathrm{~s}, 1 \mathrm{H}) .{ }^{13} \mathrm{C}$ NMR $\left.\left(100 \mathrm{MHz}, \mathrm{DMSO}-d_{6}\right)+\mathrm{TFA}-d\right) \delta 48.6,66.4$, 102.7 (d, J 24 Hz), 110.6, 117.1, 117.2, 122.4, 123.2, 125.8, 128.6 (d, J 4 Hz), 129.3, 138.2, 148.0, 150.0, 150.75, 150.84, 152.8, 157.5 (d, J $244 \mathrm{~Hz}), 166.1$. MS (ESI +ve) $\mathrm{m} / z 418.1676\left(\mathrm{MH}^{+}\right) \mathrm{C}_{23} \mathrm{H}_{21} \mathrm{FN}_{5} \mathrm{O}_{2}{ }^{+}$requires $418.1674(\Delta=$ $0.5 \mathrm{ppm})$.

$\mathbf{N}$-(4-Morpholinophenyl)-2-(pyrid-2-yl)-1H-benzo[d]imidazole-6-carbothioamide (11s). Lawesson's reagent (1.661 g, $4.11 \mathrm{mmol}, 1.6$ equiv) was added to a stirred suspension of the amide $11_{\mathrm{o}}(2.025 \mathrm{~g}, 5.07 \mathrm{mmol}) \mathrm{in}$ chlorobenzene $(20 \mathrm{~mL})$, and the mixture heated to reflux for $90 \mathrm{~min}$. The mixture was cooled, diluted with methanol $(200 \mathrm{~mL})$ and the insoluble material removed by hot filtration. The filtrate was evaporated and the residue recrystallized from hot ethanol to give $11_{\mathrm{s}}$ as a mustard-yellow solid $(1.203 \mathrm{~g}, 57 \%), \mathrm{mp} 170{ }^{\circ} \mathrm{C}(\mathrm{dec}) .{ }^{1} \mathrm{H}$ NMR (400 MHz, DMSO-d + TFA-d) $\delta 3.08-3.17(\mathrm{~m}, 4 \mathrm{H}), 3.70-3.78(\mathrm{~m}, 4 \mathrm{H}), 6.98(\mathrm{~d}, J 9.2 \mathrm{~Hz}, 2 \mathrm{H}), 7.48-7.89(\mathrm{~m}$, $5 \mathrm{H}), 8.02$ (dd, J $7.6 \mathrm{~Hz}, 1 \mathrm{H}), 8.09$ (br s, $1 \mathrm{H}), 8.35(\mathrm{~d}, J 7.8 \mathrm{~Hz}, 1 \mathrm{H}), 8.75(\mathrm{~d}, J 4.3 \mathrm{~Hz}, 1 \mathrm{H}), 11.55(\mathrm{~s}, 1 \mathrm{H}) .{ }^{13} \mathrm{C} \mathrm{NMR}$ $\left(100 \mathrm{MHz}\right.$, DMSO- $d_{6}+$ TFA-d) $\delta 48.8,66.5,113.9,113.96,114.04,114.1,114.3,114.4,114.9,115.8,122.0,122.2$, 123.7, 125.5, 125.6, 126.9, 127.5, 128.8, 130.7, 132.6, 132.8, 132.9, 133.3, 133.4, 133.5, 137.9, 138.2, 148.3, $149.5,150.0,152.9,161.6,162.2,196.7$. Additional ${ }^{13} \mathrm{C}$ NMR signals are attributed to a phosphorus containing impurity which was unable to be removed. MS $(\mathrm{ESI}+\mathrm{ve}) \mathrm{m} / z 416.1543\left(\mathrm{MH}^{+}\right) \mathrm{C}_{23} \mathrm{H}_{22} \mathrm{~N}_{5} \mathrm{OS}^{+}$requires $416.1540(\Delta$ $=0.7 \mathrm{ppm})$.

4-\{2-[2-(Pyrid-2-yl)-1H-benzo[d] imidazol-6-yl]benzo[d]thiazol-6-yl\}morpholine (6). Lawesson's reagent (2.107 $\mathrm{g}, 5.21 \mathrm{mmol}, 1.6$ equiv) was added to a stirred suspension of the amide $13 \mathrm{o}(2.881 \mathrm{~g}, 6.51 \mathrm{mmol}) \mathrm{in}$ chlorobenzene $(30 \mathrm{~mL})$, and the mixture heated to reflux for $3 \mathrm{~h}$. The mixture was then cooled, diluted with ethanol $(200 \mathrm{~mL})$, filtered through a plug of silica gel and the filtrate evaporated in vacuo. The solid residue was triturated with methanol $(10 \mathrm{~mL})$ to give a friable yellow solid, which was filtered off and washed with water. This solid was applied to a Reveleris silica cartridge and eluted with a dichloromethane/methanol gradient to 
give one major fraction. Evaporation of the solvent followed by trituration with ether $(2 \mathrm{~mL})$ afforded 6 as a pale yellow solid (0.785 g, 29\%) $270{ }^{\circ} \mathrm{C}(\mathrm{dec}) .{ }^{1} \mathrm{H}$ NMR (400 MHz, DMSO- $d_{6}+$ TFA-d) $\delta 3.20-3.31(\mathrm{~m}, 4 \mathrm{H}), 3.75-3.84$ $(\mathrm{m}, 4 \mathrm{H}), 7.3(\mathrm{dd}, J 9.2,1.9 \mathrm{~Hz}, 1 \mathrm{H}), 7.63-7.78(\mathrm{~m}, 2 \mathrm{H}), 7.83-7.98(\mathrm{~m}, 2 \mathrm{H}), 8.08(\mathrm{~d}, J 8.4 \mathrm{~Hz}, 1 \mathrm{H}), 8.19(\mathrm{dd}, J 8.0 \mathrm{~Hz}$, $1 \mathrm{H}), 8.33(\mathrm{~s}, 1 \mathrm{H}), 8.63(\mathrm{~d}, J 7.6 \mathrm{~Hz}, 1 \mathrm{H}), 8.84(\mathrm{~d}, J 2.8 \mathrm{~Hz}, 1 \mathrm{H}) .{ }^{13} \mathrm{C}$ NMR $\left(100 \mathrm{MHz}, \mathrm{DMSO}-d_{6}\right) \delta$ 49.3, 66.5, 106.9, $113.9,114.1,116.6,122.4,122.6,123.1,125.9,128.8,132.8,132.9,136.6,138.2,147.7,147.9,149.7,150.1$, 152.8, 164.7. MS (ESI +ve) $\mathrm{m} / \mathrm{z} 414.1407\left(\mathrm{MH}^{+}\right) \mathrm{C}_{23} \mathrm{H}_{20} \mathrm{~N}_{5} \mathrm{OS}^{+}$requires $414.1383(\Delta 5.8 \mathrm{ppm})$.

4-\{2-[2-(Pyrid-2-yl)-1H-benzo[d] imidazol-6-yl]benzo[d][1,3]selenazol-6-yl\}morpholine (7). Woollins' reagent (107.9 $\mathrm{mg}, 0.203 \mathrm{mmol}$ ) was stirred in pyridine $(0.5 \mathrm{~mL})$ at room temperature under nitrogen for $30 \mathrm{~min}$. Chlorobenzene $(1.5 \mathrm{~mL})$ and amide $130(212.0 \mathrm{mg}, 0.508 \mathrm{mmol})$ were then added, and the mixture heated to $130{ }^{\circ} \mathrm{C}$ in a sealed tube for $48 \mathrm{~h}$. The mixture was diluted with water $(5 \mathrm{~mL})$, stirred for $2 \mathrm{~min}$, diluted with a further $20 \mathrm{~mL}$ of brine, and extracted into $n$-butanol $(30 \mathrm{~mL})$. The organic phase was dried $\left(\mathrm{MgSO}_{4}\right)$, filtered through silica, then applied to a SNAP silica cartridge and eluted with a dichloromethane/methanol gradient to give 7 as the first major fraction. Evaporation of the solvent afforded 7 as a light yellow solid (30.0 mg, 13\%), mp $240{ }^{\circ} \mathrm{C}(\mathrm{dec}) .{ }^{1} \mathrm{H}$ NMR $\left(400 \mathrm{MHz}\right.$, DMSO- $d_{6}+$ TFA-d) $\delta 3.09-3.27(\mathrm{~m}, 4 \mathrm{H}), 3.63-3.84(\mathrm{~m}, 4 \mathrm{H}), 7.16(\mathrm{dd}, \mathrm{J} 8.8,2.0$ $\mathrm{Hz}, 1 \mathrm{H}), 7.53-7.62(\mathrm{~m}, 1 \mathrm{H}), 7.66(\mathrm{~d}, J 2.0 \mathrm{~Hz}, 1 \mathrm{H}), 7.75(\mathrm{~d}, J 8.8 \mathrm{~Hz}, 1 \mathrm{H}), 7.89$ [d, J $8.9 \mathrm{~Hz}, 2 \mathrm{H}$ (overlapping)], 8.04 (dd, J 7.6, 7.6 Hz, 1H), $8.19(\mathrm{~s}, 1 \mathrm{H}), 8.37(\mathrm{~d}, J 7.6 \mathrm{~Hz}, 1 \mathrm{H}), 8.77(\mathrm{~d}, J 3.6 \mathrm{~Hz}, 1 \mathrm{H}) .{ }^{13} \mathrm{C} \mathrm{NMR}\left(100 \mathrm{MHz}, \mathrm{DMSO}-d_{6}\right) \delta$ 49.1, 66.5, 110.5, 114.1, 116.0, 117.0, 122.4, 123.4, 124.5, 125.9, 131.5, 138.3, 138.9, 139.8, 141.2, 147.7, 149.2, 149.4, 150.1, 152.7, 168.6. MS (ESI +ve) $m / z 462.0826\left(\mathrm{MH}^{+}\right) \mathrm{C}_{23} \mathrm{H}_{20} \mathrm{~N}_{5} \mathrm{OSe}^{+}$requires $462.0828(\Delta=0.4 \mathrm{ppm})$.

Ethyl(5-fluoro-2-nitrophenyl)tellane (16). To a stirred solution of the aniline 14 (0.997 g, $6.39 \mathrm{mmol})$ and boron trifluoride etherate $\left(1.92 \mathrm{~mL}, 7.6 \mathrm{mmol}, 1.2\right.$ equiv) in dichloromethane $(20 \mathrm{~mL})$ at $0{ }^{\circ} \mathrm{C}$, was added slowly $t$-butyl nitrite (1.14 mL, $9.5 \mathrm{mmol}, 1.5$ equiv) to form a yellow gum. This was warmed to room temperature and stirred under argon for a further $30 \mathrm{~min}$. The light yellow supernatant was decanted off, and the residue triturated with ether ( $5 \mathrm{~min}$ ) before briefly drying in vacuo to give the diazonium salt $\mathbf{1 5}$ (the salt was able to be stored at -20 ${ }^{\circ} \mathrm{C}$ for up to $18 \mathrm{~h}$ before use). The diazonium salt 15 was dissolved in chloroform $(20 \mathrm{~mL})$, cooled to $0^{\circ} \mathrm{C}, 18$ crown-6 (0.040 g, $0.15 \mathrm{mmol})$ added, followed by ethereal diethyl ditelluride (43\%, $3.33 \mathrm{~g}, 4.57 \mathrm{mmol})$. Potassium acetate $(1.28 \mathrm{~g}, 13.1 \mathrm{mmol})$ was then added, and the mixture stirred protected from light at room temperature for $4 \mathrm{~h}$. The mixture was then filtered through celite and the filtrate concentrated to afford a dark brown oil. The oil was applied to a Reveleris $80 \mathrm{~g}$ silica cartridge and eluted with a petroleum ether (b.p. 40-60 $\left.{ }^{\circ} \mathrm{C}\right)$ /dichloromethane gradient over four runs to give 16 as orange needles (665 mg, 35\%), mp 54.5-55.2 ${ }^{\circ} \mathrm{C} .{ }^{1} \mathrm{H}$ $\operatorname{NMR}\left(400 \mathrm{MHz}, \mathrm{CDCl}_{3}\right) \delta 1.64-1.76(\mathrm{~m}, 3 \mathrm{H}), 2.81(\mathrm{q}, J 7.8 \mathrm{~Hz}, 2 \mathrm{H}), 7.01-7.09(\mathrm{~m}, 1 \mathrm{H}), 7.33(\mathrm{dd}, J 8.6,2.6 \mathrm{~Hz}), 8.41$ (dd, J 9.4, $5.1 \mathrm{~Hz}) .{ }^{13} \mathrm{C} \mathrm{NMR}\left(100 \mathrm{MHz}, \mathrm{CDCl}_{3}\right) \delta 3.0,14.6,114.0$ (d, J $\left.25 \mathrm{~Hz}\right), 119.5$ (d, J $\left.25 \mathrm{~Hz}\right), 123.4,123.5,129.1$ (d, J $10 \mathrm{~Hz}), 165.1$ (d, J $261 \mathrm{~Hz})$.

2-(Ethyltellanyl)-4-fluoroaniline (17). The nitrobenzene 16 (1.013 mmol) was dissolved in methanol (10 mL) and placed in a water bath $\left(20^{\circ} \mathrm{C}\right)$ under argon. Sodium borohydride ( $236.5 \mathrm{mg}, 6.25 \mathrm{mmol}, 6$ equiv) and cobalt (II) sulfate hexahydrate $(36.8 \mathrm{mg}, 0.131 \mathrm{mmol}, 0.1$ equiv) was then added and the mixture stirred for $30 \mathrm{~min}$. The solvent was then removed in vacuo and the residue suspended in ether $(20 \mathrm{~mL})$. The suspension was filtered through celite, washing with ether $(2 \times 30 \mathrm{~mL})$, and the filtrate concentrated to give the aniline 17 as an orange solid (628 mg, quantitative). ${ }^{1} \mathrm{H}$ NMR (500 MHz, CDCl 3 ) $\delta 1.21$ (t, J $\left.7.5 \mathrm{~Hz}, 3 \mathrm{H}\right), 2.81$ (q, J $\left.7.5 \mathrm{~Hz}, 2 \mathrm{H}\right), 4.1$ (br s, $2 \mathrm{H}$ ), 6.73 (dd, J 6.7, 3.9 Hz, 1H), 6.88 (ddd, J 8.4, 8.4, $2.8 \mathrm{~Hz}, 1 \mathrm{H}$ ), 7.43 (dd, J 6.4, $2.8 \mathrm{~Hz}, 1 \mathrm{H}$ ). MS (ESI +ve) $\mathrm{m} / \mathrm{z}$ $269.9928\left(\mathrm{MH}^{+}\right) \mathrm{C}_{8} \mathrm{H}_{11} \mathrm{FNTe}^{+}$requires $269.9932(\Delta=1.5 \mathrm{ppm})$.

$\mathbf{N}$-\{2-(Ethyltellanyl)-4-fluorophenyl\}-2-(pyrid-2-yl)-1H-benzo[d]imidazole-6-carboxamide (18). To a solution of the aniline $17(270 \mathrm{mg}, 1.01 \mathrm{mmol})$ and triethylamine $\left(1.0 \mathrm{~mL}\right.$, distilled from $\left.\mathrm{CaH}_{2}\right)$ in anhydrous $\mathrm{N}, \mathrm{N}$ dimethylacetamide $(10 \mathrm{~mL}$ ) was added the acid chloride 10 (404 mg, $1.37 \mathrm{mmol}, 1.4$ equiv), and the mixture 
stirred at room temperature under argon for $40 \mathrm{~h}$. The solution was then diluted with water $(200 \mathrm{~mL})$ and the $\mathrm{pH}$ adjusted to 5-6 with saturated $\mathrm{NH}_{4} \mathrm{Cl}$ solution. The resulting precipitate was filtered off and dried in vacuo, affording 18 as a brown powder (265 mg, 54\%), $\mathrm{mp} 102{ }^{\circ} \mathrm{C}$ (dec.), which was used without further purification. ${ }^{1} \mathrm{H}$ NMR $\left(500 \mathrm{MHz}, \mathrm{MeOH}-d_{4}+\mathrm{TFA}-d\right) \delta 1.86(\mathrm{t}, J 7.6 \mathrm{~Hz}, 3 \mathrm{H}), 3.11$ (q, J 7.6 Hz, 2H), 7.32-7.36 (m, 1H), 7.74-7.83 $(\mathrm{m}, 2 \mathrm{H}), 8.03-8.13(\mathrm{~m}, 2 \mathrm{H}), 8.23-8.30(\mathrm{~m}, 2 \mathrm{H}), 8.58-8.66(\mathrm{~m}, 2 \mathrm{H}), 9.03(\mathrm{~d}, J 4.5 \mathrm{~Hz}, 1 \mathrm{H})$. MS (ESI +ve) $\mathrm{m} / z 491.0525$ $\left(\mathrm{MH}^{+}\right) \mathrm{C}_{21} \mathrm{H}_{18} \mathrm{FN}_{4} \mathrm{OTe}^{+}$requires $491.0521(\Delta=0.8 \mathrm{ppm})$.

6-Fluoro-2-\{2-(pyrid-2-yl)-1H-benzo[d]imidazol-6-yl\}benzo[d][1,3]tellurazole (19). To a solution of the amide $18(105 \mathrm{mg}, 0.216 \mathrm{mmol})$ in dioxane $\left(5.0 \mathrm{~mL}\right.$, distilled from $\mathrm{Na}$ ) and triethylamine $\left(0.7 \mathrm{~mL}\right.$, distilled from $\left.\mathrm{CaH}_{2}\right)$ was added distilled $\mathrm{POCl}_{3}(0.1 \mathrm{~mL}, 1 \mathrm{mmol})$ and the mixture refluxed for $2 \mathrm{~h}$. After cooling to room temperature, the mixture was diluted with water $(20 \mathrm{~mL})$, the $\mathrm{pH}$ adjusted to 7 with solid $\mathrm{NH}_{4} \mathrm{Cl}$, then extracted into $n$-butanol. The organic phase was washed with brine, dried $\left(\mathrm{MgSO}_{4}\right)$ and evaporated to give a brown oil which was applied to a Reveleris $40 \mathrm{~g}$ silica cartridge. Elution with a dichloromethane/methanol gradient afforded the benzotellurazole 19 as the first major fraction (yellow powder, $8.3 \mathrm{mg}, 8.7 \%$ ), $\mathrm{mp} 224.2-227.3^{\circ} \mathrm{C} .{ }^{1} \mathrm{H}$ NMR $(600$ $\left.\mathrm{MHz}, \mathrm{MeOH}-d_{4} / \mathrm{CDCl}_{3}+\mathrm{TFA}-d\right) \delta$ 7.15-7.18 $(\mathrm{m}, 1 \mathrm{H}), 7.43-7.45(\mathrm{~m}, 1 \mathrm{H}), 7.55-7.57(\mathrm{~m}, 1 \mathrm{H}), 7.70(\mathrm{~d}, J 6.9 \mathrm{~Hz}, 1 \mathrm{H})$, 7.80-7.82 (m, 1H), 7.90-7.93 (m, 1H), 8.05-8.07 (m, 1H), $8.12(\mathrm{~s}, 1 \mathrm{H}), 8.32(\mathrm{~d}, J 5.6 \mathrm{~Hz}, 1 \mathrm{H}), 8.69(\mathrm{~d}, J 2.8 \mathrm{~Hz}, 1 \mathrm{H})$. ${ }^{13} \mathrm{C} \mathrm{NMR}\left(125 \mathrm{MHz}, \mathrm{MeOH}-d_{4} / \mathrm{CDCl}_{3}+\right.$ TFA-d) $\delta 118.6,119.0,119.4$ (d, J $\left.62 \mathrm{~Hz}\right), 121.4,121.6,126.1,128.9,129.5$, 129.7, 130.2, 130.3, 138.68, 138.75, 141.4 (d, J 46 Hz), 150.0, 155.9 (d, J 265 Hz), 162.4, 164.4, 177.0. MS (ESI +ve) $m / z 445.0102\left(\mathrm{MH}^{+}\right) \mathrm{C}_{19} \mathrm{H}_{12} \mathrm{FN}_{4} \mathrm{Te}^{+}$requires $445.0103(\Delta=0.2 \mathrm{ppm})$.

Crystallography. Intensity data for 6, 7, and 16 were collected on a Rigaku SuperNova at 130.0(1) K using Mo$K \alpha$ radiation. The temperature was maintained using an Oxford Cryostream cooling device. The structures were solved by direct methods and difference Fourier synthesis. ${ }^{31}$ Thermal ellipsoid plot were generated using the program Mercury ${ }^{32}$ integrated within the WINGX ${ }^{33}$ suite of programs. Structures 6 and 16 have been published as private communications in the $\mathrm{CSD}^{19,21} \mathrm{Crystal}$ data for 7. $\mathrm{C}_{23} \mathrm{H}_{19} \mathrm{~N}_{5} \mathrm{OSe}$.(DMSO), $M=538.52, T=130.0 \mathrm{~K}, \lambda=$ $0.70173 \AA$, Monoclinic, space group $\mathrm{P} 2{ }_{1} / \mathrm{c} a=15.436(3) b=11.5965(7), c=15.058(2) \AA, \beta=117.72(2)^{\circ} \mathrm{V}=$ 2386.0(7) $\AA^{3}, Z=4, D_{c}=1.499 \mathrm{mg} \mathrm{M}^{-3} \mu($ Mo-K $\alpha) 1.695 \mathrm{~mm}^{-1}, \mathrm{~F}(000)=1104$ crystal size $0.39 \times 0.36 \times 0.06 \mathrm{~mm}^{3}$, 17835 reflections measured $\theta_{\max }=30.19^{\circ}, 6190$ independent reflections $[R($ int $)=0.0463$ ], the final $R$ was 0.0972

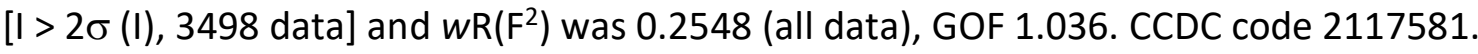

DNA Binding assays. A Cary Bio 300 UV-Vis Spectrophotometer was used with quartz cuvettes to measure the absorbance spectra at each DNA concentration. Stock solutions were prepared as per table 1. A baseline is measured with $1050 \mu \mathrm{L}$ TEN DMSO $\times 1$, then the ligand is added to give a concentration of $1 \mathrm{mg} \cdot \mathrm{mL}^{-1}$. DNA solutions are then added sequentially as per Table 1 . Measurements are repeated at each concentration after mixing by pipette to give concordant spectra.

Cell Culture. HeLa cells were cultured in phenol-red free DMEM (Gibco, Catalog Number: A18967-01) supplemented with 10\% fetal bovine serum (Sigma, Australia origin, Catalog Number: F9423) and $4 \mathrm{mM}$ glutamine (Sigma, Catalog Number: $59202 \mathrm{C}$ ) at $37{ }^{\circ} \mathrm{C}$ in $5 \% \mathrm{CO}_{2}$ air with humidification.

Cell Staining. M2PB and 7 were dissolved in DMSO at $5 \mathrm{mM}$ stock concentration. Stock solution of dye were kept at $-20{ }^{\circ} \mathrm{C}$ in the dark. HeLa cells $\left(1.4 \times 10^{4}\right)$ were plated on an ibidi $\mu$ Slide 8 Well, ibiTreat (ibidi, Catalog number: 80826) $24 \mathrm{~h}$ prior to dye application. Plated cells were treated with freshly diluted dye ( $5 \mu \mathrm{M}$ for $\mathbf{M} 2 \mathrm{~PB}$ and 7 in DMEM) for $30 \mathrm{~min}$ at $37{ }^{\circ} \mathrm{C}$. Cells were rinsed with PBS and then fixed on plate with $4 \%(\mathrm{w} / \mathrm{v})$ paraformaldehyde (PFA) in PBS for 10 min at room temperature.

Confocal Laser Scanning Microscopy. After staining, HeLa cells were fixed with $4 \%(\mathrm{w} / \mathrm{v})$ paraformaldehyde in PBS for 10 min at room temperature. Images were acquired on a Zeiss Elyra LSM880 microscope using a 63× oilimmersion objective $1.4 \mathrm{NA}$, with a pixel frame size set at $512 \times 512$ and a pixel dwell time of $16.38 \mu \mathrm{s}$. For MP2B 
20 and selenium analog 7 (excitation: 405 nm; emission: 490 - 590 nm, 405 nm dichroic). Laser power for 405 $\mathrm{nm}$ excitation source was set at $1.0 \%$.

\section{Acknowledgements}

We gratefully acknowledge Sirtex Medical for funding the Australian Research Council for Post Graduate Scholarships (TF and TCO).

\section{Supplementary Material}

${ }^{1} \mathrm{H}$ and ${ }^{13} \mathrm{C}$ NMR spectra for new compounds and methodology for DNA spectrophotrometric titration experiments.

\section{References}

1. Denison, L.; Haigh, A.; D'Cunha, G.; Martin, R. F. DInt. J. Radiat. Biol. 1992, 61, 69-81. https://doi.org/10.1080/09553009214550641

2. Martin, R. F.; Denison, L. Int. J. Radiat. Oncol., Biol., Phys. 1992, 23, 579-584. https://doi.org/10.1016/0360-3016(92)90014-9

3. Smith, P. J.; Anderson, C. O. Int. J. Radiat. Biol. Relat. Stud. Phys., Chem. Med. 1984, 46, 331-344. https://doi.org/10.1093/fs/XXXVIII.3.331

4. Young, S. D.; Hill, R. P. Br. J. Cancer 1989, 60, 715-721. https://doi.org/10.1038/bjc.1989.346

5. Martin, R. F.; Broadhurst, S.; D'Abrew, S.; Budd, R.; Sephton, R.; Reum, M.; Kelly, D. P. Br. J. Cancer, Suppl. 1996, 27, S99-101.

6. Martin, R. F.; Holmes, N. Nature (London) 1983, 302, 452-454. https://doi.org/10.1038/302452a0

7. Murray, V.; Martin, R. F. Nucleic Acids Res. 1994, 22, 506-513. https://doi.org/10.1093/nar/22.3.506

8. Harshman, K. D.; Dervan, P. B. Nucleic Acids Res. 1985, 13, 4825-4835 https://doi.org/10.1093/nar/13.13.4825

9. Teng, M.; Usman, N.; Frederick, C. A.; Wang, A. H. J. Nucleic Acids Res. 1988, 16, 2671-2690. https://doi.org/10.1093/nar/16.6.2671

10. Loontiens, F. G.; Regenfuss, P.; Zechel, A.; Dumortier, L.; Clegg, R. M Biochem. 1990, 29, 9029-9039. https://doi.org/10.1021/bi00490a021

11. Martin, R. F.; Broadhurst, S.; Reum, M. E.; Squire, C. J.; Clark, G. R.; Lobachevsky, P. N.; White, J. M.; Clark, C.; Sy, D.; Spotheim-Maurizot, M.; Kelly, D. P.et al., Cancer Res. 2004, 64, 1067-1070. https://doi.org/10.1158/0008-5472.CAN-03-2423

12. Martin, R. F.; Anderson, R. F. Int. J. Radiat. Oncol., Biol., Phys. 1998, 42, 827-831. 
https://doi.org/10.1016/S0360-3016(98)00316-2

13. Kakkar, R.; Pathak, S. M. J. Mol. Struct. THEOCHEM 2005, 714, 35-42.

https://doi.org/10.1016/j.theochem.2004.09.045

14. Tsoi, M.; Do, T. T.; Tang, V. J.; Aguilera, J. A.; Milligan, J. R. Org. Biomol. Chem. 2010, 8, 2553-2559. https://doi.org/10.1039/b922749k

15. Kouvaris, J. R.; Kouloulias, V. E.; Vlahos, L. J. Oncologist 2007, 12, 738-747. https://doi.org/10.1634/theoncologist.12-6-738

16. Beno, B. R.; Yeung, K.-S.; Bartberger, M. D.; Pennington, L. D.; Meanwell, N. A. J. Med. Chem. 2015, 58, 4383-4438.

https://doi.org/10.1021/jm501853m

17. Bleiholder, C.; Werz, D.B.; Koppel, H.; Gleiter, R. J. Am. Chem. Soc. 2006, 128, 2666-2674. https://doi.org/10.1021/ja056827g

18. Garrett, E.; Gibson, G. L.; Straus, R. N.; Seferos, D. S.; Taylor, M. S. J. Am. Chem. Soc. 2015, 137, 4126-4133. https://doi.org/10.1021/ja512183e

19. Garrett, G. E.; Carrera, E. I.; Seferos, D. S.; Taylor, M. S. Chem. Commun. 2016, 52, 9881-9884. https://doi.org/10.1039/C6CC04818H

20. Vogel, L.; Wonner, P.; Huber, S. M. Angew. Chem., Int. Ed. 2019, 58, 1880-1891. https://doi.org/10.1002/anie.201809432

21. Martin, R. F.; White, J.; Lobachevsky, P.; Winkler, D.; Skene, C.; Marcuccio, S. Radioprotector compounds and methods AU2011238421.

22. Gupta, A.; Rawat, S. J. Curr. Pharm. Res. 2010, 3, 13-23.

23. White, J. M.; Fellowes, T. CSD Communication REFCODE: LOWNAP. CSD code: 1963341.

24. Wyvette Wee, PhD Thesis, 'Synthesis and X-ray crystallographic studies of novel radioprotectors derived from Hoechst 33258' 2013 The University of Melbourne.

25. White, J. M.; Fellowes, T. CSD Communication REFCODE: WETROF. CSD Code 1814593.

26. Bucevičius, J.; Lukinavičius, G.; Gerasimaitè, R. Chemosensors 2018, 6, 18 (article no.). https://doi.org/10.3390/chemosensors6020018

27. Lobachevsky, P. N.; Vasireddy, R. S.; Broadhurst, S.; Sprung, C. N.; Karagiannis, T. C.; Smith, A. J.; Radford, I. R.; McKay, M. J.; Martin, R. F. Int. J. Radiat. Biol. 2011, 87, 274-283.

https://doi.org/10.3109/09553002.2011.530333

28. White, J. M.; Skene, C. E.; Deadman, J.; Epa, R.; Foenander, S.; Hamer, K.; Fellowes, T.; Lim, S. F.; Marcuccio, S. M.; Martin, R. F. Aust. J. Chem. 2018, 74, 311-327.

https://doi.org/10.1071/CH18523

29. Levanova, E. P.; Grabel'nykh, V. A.; Russavskaya, N. N. V.; Klyba, L. V.; Albanov, A. I.; Korchevin, N. A. Russ. J. Gen. Chem. 2010, 79, 2321-2327. https://doi.org/10.1134/S1070363209110073

30. Wubulikasimu, R.; Yang, Y. B.; Xue, F.; Luo, X. J.; Shao, D. P.; Li, Y. H.; Gao, R. M.; Ye, W. D. Bull. Korean Chem. Soc. 2013, 34, 2297-2304. https://doi.org/10.5012/bkcs.2013.34.8.2297

31. Sheldrick, G. Acta Crystallogr., Sect. C 2015, 71, 3-8. https://doi.org/10.1107/S2053229614024218 
32. Macrae, C. F.; Bruno, I. J.; Chisholm, J. A.; Edgington, P. R.; McCabe, P.; Pidcock, E.; Rodriguez-Monge, L.; Taylor, R.; van de Streek, J.; Wood, P. A. J. Appl. Cryst. 2008, 41, 466-470. https://doi.org/10.1107/S0021889807067908

33. Farrugia, L. J. J. Appl. Cryst. 1999, 32, 837-838. https://doi.org/10.1107/S0021889899006020

This paper is an open access article distributed under the terms of the Creative Commons Attribution (CC BY) license (http://creativecommons.org/licenses/by/4.0/) 